Click www.researchjournal.co.in/online/subdetail.html to purchase.

INTERNATIONAL JOURNAL OF PLANT PROTECTION

- ISSN-0974-2670 | Visit us : www.researchjournal.co.in

\title{
Screening of sesame genotypes against powdery mildew disease caused by Erysiphe cichorecearum
}

\author{
S.D. Jagtap ${ }^{1}$, B.C. Game* and P.E. More ${ }^{1}$
}

Agricultural Research Station (MPKV), Niphad, Nashik (M.S.) India

${ }^{1}$ Mahatma Phule Krishi Vidyapeeth, Rahuri, Ahmednagar (M.S.) India

\section{ARITCLE INFO \\ Received : 27.07 .2020 \\ Revised : 08.09 .2020 \\ Accepted : 23.09 .2020}

KEY WORDS :

Sesame, Screening, Powdery mildew, Resistance, AUDPC
*Corresponding author: Email : bcgame@rediffmail.com

\begin{abstract}
Powdery mildew disease of sesame occurs on epidemic scale in areas of high rainfall and humidity coupled with low night temperature causing considerable yield losses. Use of host plant resistance is the practical approach to manage this disease, but proper resistance sources with combining ability for the trait are unknown. Hence, an experiment was conducted to determine resistance in sesame genotypes against powdery mildew disease. Among the twenty four genotypes screened, none was found resistant while, nine genotypes exhibited moderately resistant to tolerant reaction and 15 genotypes exhibited susceptible reaction. Apparent rate of infection value varied and at times they did not remain consistent for given genotype and also did not show a particular trend which is attributed to genetic character of the genotype. The AUDPC values differed considerably for different genotypes. The values of AUDPC and apparent rate of infection of susceptible varieties were high as compared to moderately susceptible varieties. Genotype 'JLS-302-11' and 'JLT-7' having minimum AUDPC and apparent rate of infection value showed lowest intensity of powdery mildew while, genotype 'JLT-408' having maximum AUDPC and apparent rate of infection value showed highest intensity of powdery mildew.
\end{abstract}

How to view point the article : Jagtap, S.D., Game, B.C. and More, P.E. (2020). Screening of sesame genotypes against powdery mildew disease caused by Erysiphe cichorecearum. Internat. J. Plant Protec., 13(2) : 175-179, DOI : 10.15740/HAS/IJPP/13.2/175-179, Copyright@ 2020: Hind Agri-Horticultural Society. 